\title{
Evaluation of Anti-Contamination Garments in Use at LLNL
}

\author{
K.J. Staggs \\ K.R. Wilson \\ D.P. Eadens \\ J.W. Stengel \\ Y.P. Chong
}

December 1997

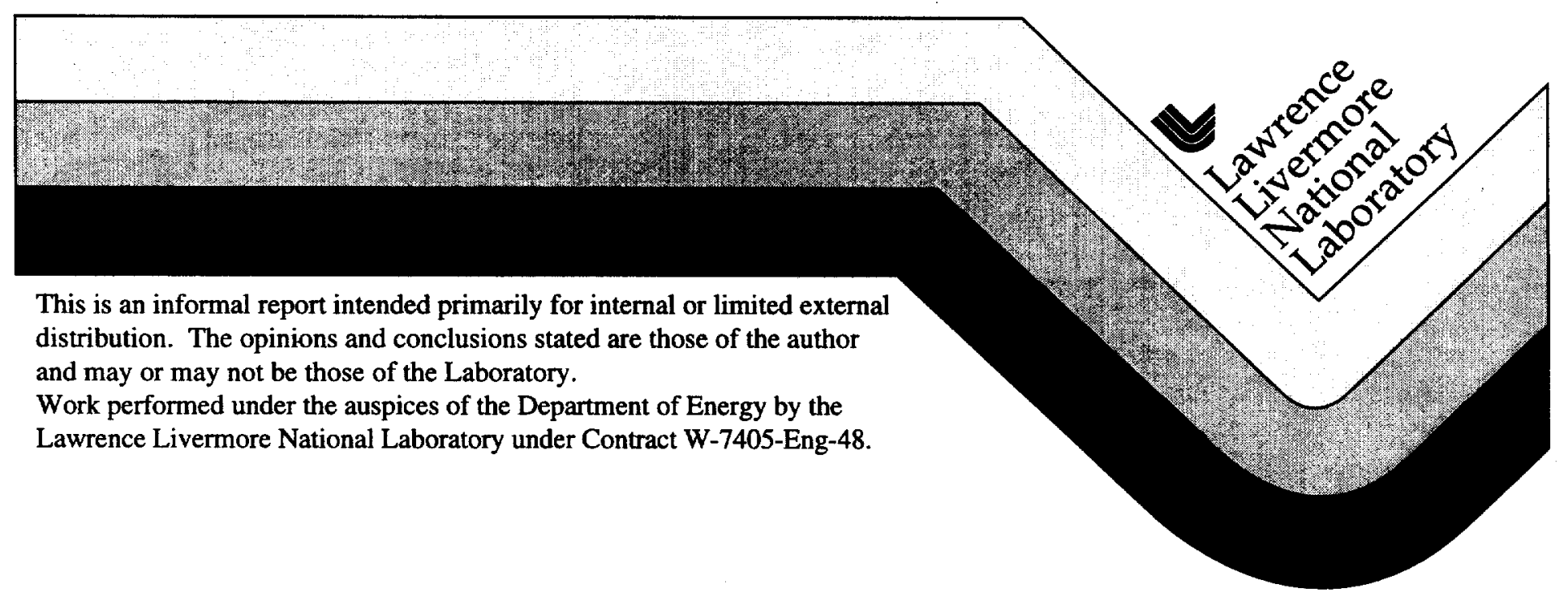




\section{DISCLAIMER}

This document was prepared as an account of work sponsored by an agency of the United States Government. Neither the United States Government nor the University of California nor any of their employees, makes any warranty, express or implied, or assumes any legal liability or responsibility for the accuracy, completeness, or usefulness of any information, apparatus, product, or process disclosed, or represents that its use would not infringe privately owned rights. Reference herein to any specific commercial products, process, or service by trade name, trademark, manufacturer, or otherwise, does not necessarily constitute or imply its endorsement, recommendation, or favoring by the United States Government or the University of California. The views and opinions of authors expressed herein do not necessarily state or reflect those of the United States Government or the University of California, and shall not be used for advertising or product endorsement purposes.

This report has been reproduced

directly from the best available copy.

Available to DOE and DOE contractors from the

Office of Scientific and Technical Information

P.O. Box 62, Oak Ridge, TN 37831

Prices available from (615) 576-8401, FTS 626-8401

Available to the public from the

National Technical Information Service

U.S. Department of Commerce

5285 Port Royal Rd.,

Springfield, VA 22161 


\title{
Evaluation of Anti-Contamination Garments in Use at LLNL
}

\author{
K.J. Staggs \\ K.R. Wilson \\ D.P. Eadens \\ J.W. Stengel \\ Y.P. Chong
}

December 1997 


\title{
Evaluation of Anti-Contamination Garments in Use at LLNL
}

\author{
Kirk J. Staggs, Kent R. Wilson, Donald P. Eadens \\ Jerry W. Stengel, and Yee Ping Chong \\ Lawrence Livermore National Laboratory \\ PO Box 808, Livermore, CA 94551
}

\begin{abstract}
This paper describes tests conducted on LLNL anti-contamination and clean-room garments using flame exposures derived from federal and industry standards. Each garment was assigned to one of three groups (low, moderate, and high) based on its fire response and performance. Test results and analysis provide guidance in selecting protective clothing for operations involving high temperatures or potential ignition sources.
\end{abstract}

\section{INTRODUCTION}

On February 13, 1997, a fatal accident occurred at the Oak Ridge National Laboratory (ORNL) when a worker's clothing caught fire during a torch-cutting operation. Following this incident, the Hazards Control Department at Lawrence Livermore National Laboratory (LLNL) conducted flammability tests of all anticontamination and clean-room garments used for operations. Of special concern was the performance of protective clothing used in areas where personnel are exposed to potential ignition sources from operations involving welding, cutting, pyrophoric metals, and other high-energy sources such as lasers. Tests were conducted to determine various parameters (ignition, flamespread rate, after-burn time, char length, amount of material consumed, and afterglow time) for each garment. The results will provide guidance in the selection of protective clothing best suited for LLNL operations involving high temperatures or potential ignition sources.

\section{TESTING}

Twenty-two anti-contamination and cleanroom garments were collected from within LLNL. Each garment was assigned a number (1-22), then subdivided alphabetically into sets (e.g., 1A-E; 2A-E; etc.) in order to apply the equivalent flame exposures specified in the American Society for Testing and Materials (ASTM) D-1230 Standard ${ }^{1}$ and the Federal Test Method (FTM) 191 Standard. ${ }^{2}$ The flame exposure for the ASTM D-1230 Standard is reasonably reproducible, so the number of samples tested for each garment was limited to three. On the other hand, the flame exposure for the FTM 191 Standard is more severe and generally burns faster, so five samples of each garment were tested and the results averaged to account for any variations in the flame-spread rate.

\section{ASTM D-1230 Standard}

To create the flame exposure specified in this standard, a small burner was fabricated using a 26-gauge needle. Butane was used as the fuel source, and the flame was adjusted to a length of $5 / 8$ inch $(1.59 \mathrm{~cm})$ and controlled with precision valves and pressure gauges. Each sample was then inserted into a specimen holder at a $45^{\circ}$ incline, with the flame positioned $3 / 4$ inch $(1.91 \mathrm{~cm})$ from the lower end of the test sample. A thread was then placed across the sample (five inches up from the exposed area) to gauge the flame spread. The sample was exposed to the test flame for approximately one second (see Fig. 1). 


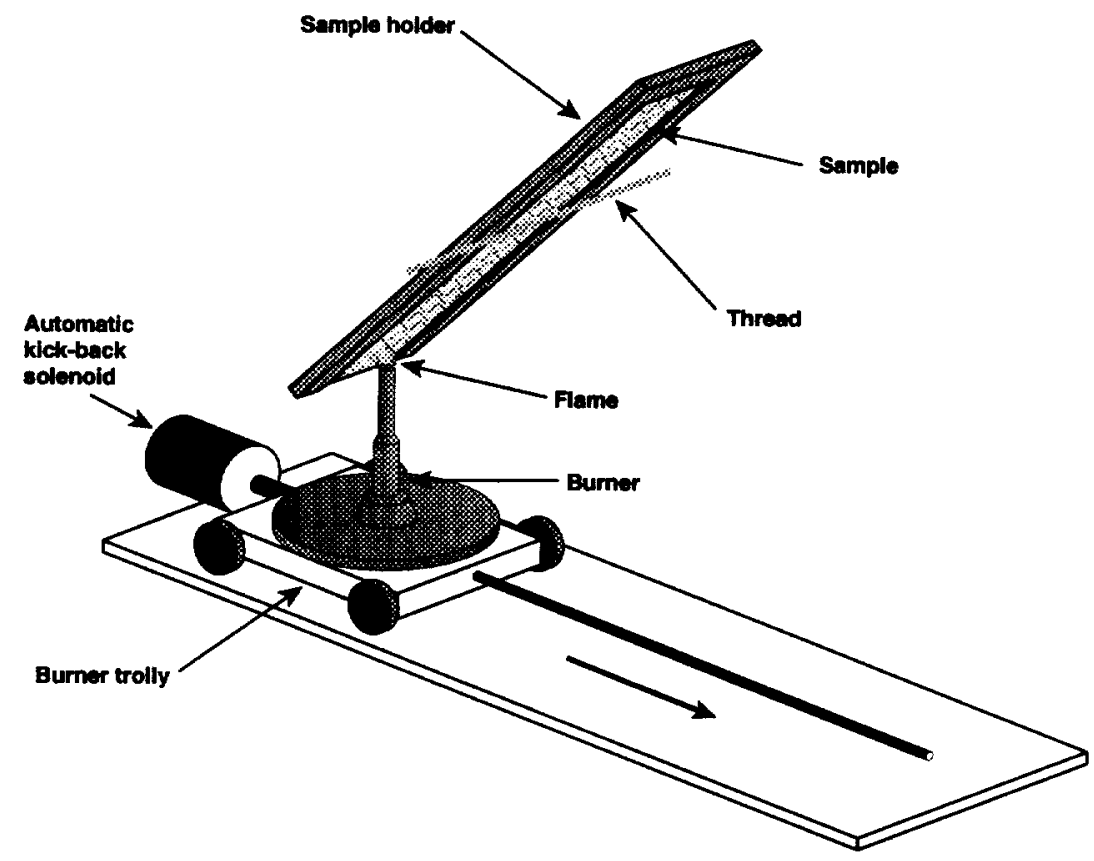

Figure 1. Test apparatus. The sample holder was placed at a $45^{\circ}$ angle for samples tested using the ASTM D-1230 flame exposure and at a $90^{\circ}$ angle for samples tested using the FTM 191 flame exposure.

Photographs and video records were taken of each test and used to calculate the flame-spread rate as well as other parameters for each sample. In some tests, the lower section of the sample being tested melted or burned but the flame did not extend up to the thread. In these cases, the total area burned or melted was measured and correlated with the length of burn time to derive an omni-directional flame-spread rate (i.e., area/sec). These results can be found in Table A-1, Appendix A.

\section{FTM 191 Standard}

The flame exposure for this standard was created using a $3 / 8$-inch $(0.95 \mathrm{~cm})$ diameter Bunsen burner, with the vents completely closed, and a special gas mixture as required by the standard. The flame was adjusted to extend approximately $1-1 / 2$ inch $(3.81 \mathrm{~cm})$ above the burner. Each sample was then placed in a $3 \times 12$ inch $(7.62 \times 30.05 \mathrm{~cm})$ specimen holder and held vertically $3 / 4$ inch $(1.91 \mathrm{~cm})$ above the flame. Samples were exposed to the flame for 12 seconds. If ignition occurred, the sample was allowed to burn until either it was consumed or the fire selfextinguished. The burn time was recorded after the flame was removed. If there was any afterglow, it was recorded from the time the flame went out until the glowing stopped. In cases where the afterglow time was lengthy, it was recorded as greater than a minute. A video record was made of each test and used to calculate the measurements for the various parameters. These results can be found in Table A-2, Appendix A.

Char-length measurements were calculated for test samples that did not completely burn. As required by the FTM 191 standard, a 4-ounce weight was attached to the sample corner exposed to the flame while the opposite corner was lifted. The material was allowed to tear (or pull apart) as the weight was lifted. These measurements can also be found in Table A-2, Appendix A. 


\section{RANKING PROCESS}

The 22 anti-contamination garments tested were categorized into one of three groups (low, moderate, and high) based on their ignition characteristics and flamespread rates. Table 1 summarizes the garments tested and their group ranking. The criteria used in the ranking process are shown in Table 2. Figures 2 through 4 provide examples of the test results for each group.
The garment's ease of ignition constituted one of the ranking criteria. Ignition was considered to occur if the garment burned for more than one second after flame removal. Brief ignition is defined as obvious burning that selfextinguished within one second of flame removal, while sustained ignition is continued burning for three or more seconds after flame removal. Limited ignition falls between sustained and brief ignition.

Table 1. Anti-contamination garments collected and tested.

\begin{tabular}{|c|c|c|c|}
\hline Sample & Description & Model/manufacturer & Group \\
\hline 1 & Green paper coveralls & Tempro/Kappler & Low \\
\hline 2 & Blue paper coveralls & Prevail/Kimberly-Clark & Low \\
\hline 3 & Yellow-coated paper coveralls & -“ & Moderate \\
\hline 4 & Blue paper coveralls & Sontara/Durafab & Low \\
\hline 5 & $\begin{array}{l}\text { Blue- and white-coated paper } \\
\text { coveralls }\end{array}$ & $\begin{array}{l}\text { Micro Clean 2-1-2/ } \\
\text { Pharmeseal }\end{array}$ & High \\
\hline 6 & White-coated paper coveralls & Tyvek/Kappler & High \\
\hline 7 & Blue cloth coveralls & $\begin{array}{l}\text { Maximun/Dryden } \\
\text { Engineering Co. }\end{array}$ & High \\
\hline 8 & White cloth coveralls & $\begin{array}{l}\text { Maximun/Dryden } \\
\text { Engineering Co. }\end{array}$ & High \\
\hline $\begin{array}{c}9 \\
10\end{array}$ & $\begin{array}{l}\text { Yellow cloth coveralls } \\
\text { White-coated paper coveralls }\end{array}$ & - & $\begin{array}{l}\text { Moderate } \\
\text { Moderate }\end{array}$ \\
\hline 11 & $\begin{array}{l}\text { 100\% polypropylene coveralls, } \\
\text { style GB-1030 }\end{array}$ & - & Moderate \\
\hline 12 & $\begin{array}{l}\text { Blue lab coat, } 65 \% \text { polyester } \\
\text { and } 35 \% \text { cotton }\end{array}$ & - & Moderate \\
\hline 13 & $\begin{array}{l}\text { Orange lab coat, } 65 \% \text { polyester } \\
\text { and } 35 \% \text { cotton }\end{array}$ & Euclid & Moderate \\
\hline 14 & $\begin{array}{l}\text { Blue lab coat, } 50 \% \text { polyester } \\
\text { and } 50 \% \text { cotton }\end{array}$ & $\begin{array}{l}\text { Uniforms Manufacturer, } \\
\text { Inc. }\end{array}$ & Moderate \\
\hline 15 & White and orange lab coat & 一" & Moderate \\
\hline 16 & Blue lab coat & 一" & Moderate \\
\hline 17 & $\begin{array}{l}\text { Blue lab coat, } 65 \% \text { dacron and } \\
35 \% \text { cotton }\end{array}$ & KWB Manufacturing Co. & Moderate \\
\hline 18 & $\begin{array}{l}\text { White lab coat, } 65 \% \text { polyester } \\
\text { and } 35 \% \text { cotton }\end{array}$ & Best Manufacturing, Inc. & Moderate \\
\hline 19 & Yellow cloth coveralls & Defense Apparel, Inc. & Moderate \\
\hline $\begin{array}{l}20 \\
21\end{array}$ & $\begin{array}{l}\text { White, full body suit } \\
\text { Orange lab coat, } 65 \% \text { polyester }\end{array}$ & $\begin{array}{l}\text { Tyvek/Kappler } \\
\text { Wranglers }\end{array}$ & $\begin{array}{l}\text { Moderate } \\
\text { High }\end{array}$ \\
\hline 22 & $\begin{array}{l}\text { and } 35 \% \text { cotton } \\
\text { Orange coveralls, } 65 \% \text { polyester } \\
\text { and } 35 \% \text { cotton }\end{array}$ & 一" & Moderate \\
\hline
\end{tabular}

${ }^{a}$ Model and manufacturer information was not visible on garment tags. 
Table 2. Criteria used for categorizing anti-contamination garments.

\begin{tabular}{|c|c|}
\hline IF the garment exhibited & THEN, it was placed in the \\
\hline $\begin{array}{l}\text { - Brief ignition (<1 sec) using the ASTM } \\
\text { D-1230 Standard flame exposure } \\
\text { and } \\
\text { - Limited or brief ignition }(<3.0 \mathrm{sec}) \text { and a } \\
\text { slow flame-spread rate }(<0.5 \mathrm{~cm} / \mathrm{sec}) \text { using } \\
\text { the FTM } 191 \text { Standard flame exposure }\end{array}$ & $\begin{array}{l}\text { Low group. This indicates that } \\
\text { the garment has a low } \\
\text { probability of ignition and a low } \\
\text { flame-spread rate. }\end{array}$ \\
\hline $\begin{array}{l}\text { - Limited ignition (between } 1.0 \text { and } 3.0 \mathrm{sec}) \\
\text { and a moderate flame-spread rate } \\
(\leq 1.0 \mathrm{~cm} / \mathrm{sec}) \text { using the ASTM D-1230 } \\
\text { Standard flame exposure } \\
\text { and } \\
\text { - Sustained ignition }(\geq 3.0 \mathrm{sec}) \text { and a moderate } \\
\text { flame-spread rate }(\leq 2.0 \mathrm{~cm} / \mathrm{sec}) \text { using the } \\
\text { FTM } 191 \text { Standard flame exposure }\end{array}$ & $\begin{array}{l}\text { Moderate group. This indicates } \\
\text { that the garment has a higher } \\
\text { probability of ignition than the } \\
\text { low group and a moderate flame- } \\
\text { spread rate. }\end{array}$ \\
\hline $\begin{array}{l}\text { - Sustained ignition }(\geq 3.0 \mathrm{sec}) \text { and a fast } \\
\text { flame-spread rate }(>1.0 \mathrm{~cm} / \mathrm{sec}) \text { or thread } \\
\text { time ( }>3.5 \mathrm{secs}) \text { using the ASTM D-1230 } \\
\text { Standard flame exposure } \\
\text { and } \\
\text { A fast flame-spread rate }(>2.0 \mathrm{~cm} / \mathrm{sec}) \text { using } \\
\text { the FTM } 191 \text { Standard flame exposure }\end{array}$ & $\begin{array}{l}\text { High group. This indicates that } \\
\text { the garment passed the test, but } \\
\text { will ignite with a high flame- } \\
\text { spread rate. }\end{array}$ \\
\hline
\end{tabular}

The other criteria for group ranking involved the flame-spread rate-either linear or area (omni-directional) - over a given time period. A fast flame-spread rate for samples tested using the ASTM D-1230 Standard is faster than $1.0 \mathrm{~cm}$ per second. At this rate, a flame could travel the full length of a garment at any angle less than $45^{\circ}$ from vertical in approximately two minutes. A fast flame-spread rate for samples tested using the FTM 191 Standard is faster than $2.0 \mathrm{~cm}$ per second, which could be compared to a flame traveling the full length of a garment in just over a minute. Flame-spread rates slower than these are considered to be moderate; a flame-spread rate of $0.5 \mathrm{~cm}$ or less using the FTM 191 Standard is slow.

Garments ranked in the low group will not contribute to a fire or allow flames to easily spread. These garments will melt but do not ignite, and if ignited will not burn after the energy source is removed. Garments in the moderate group resist ignition, but if ignited will burn slowly. These garments would be suitable for
LLNL operations if the user is fully aware of the hazards involved and could easily or quickly sense fire or smoke from the burning garment, allowing time to extinguish the flames. (Code of Federal Regulation, Title 29, Part 1910.132(f) requires workers to be trained on the hazards involved in and limitations of selected personal protective equipment. ${ }^{3}$ ) Garments in the high group will ignite with a high flame-spread rate. Therefore, these garments are unsuitable for operations involving high temperature, pyrotechnic operations, welding, or other tasks that might produce a spark, flame, high-energy light source, or incandescent surface.

\section{DISCUSSION}

The testing and ranking process did not take into account the burning characteristics of multi-layered clothing. Certain combinations of clothing might burn with more intensity and become difficult to extinguish in a very short time. It is also possible that 


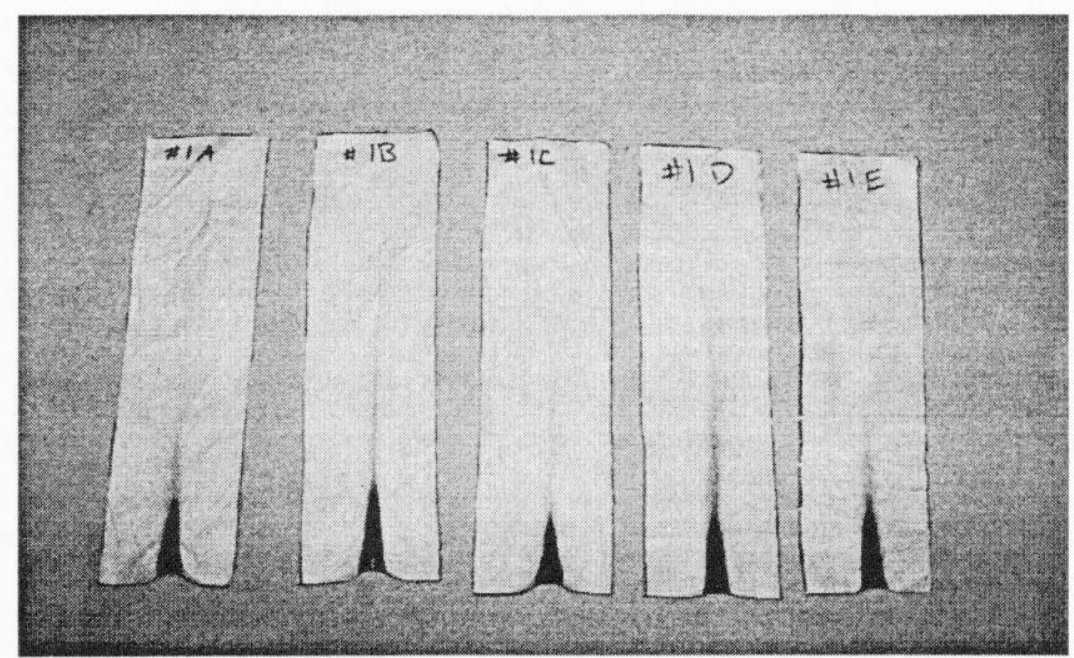

Figure 2. Low group.

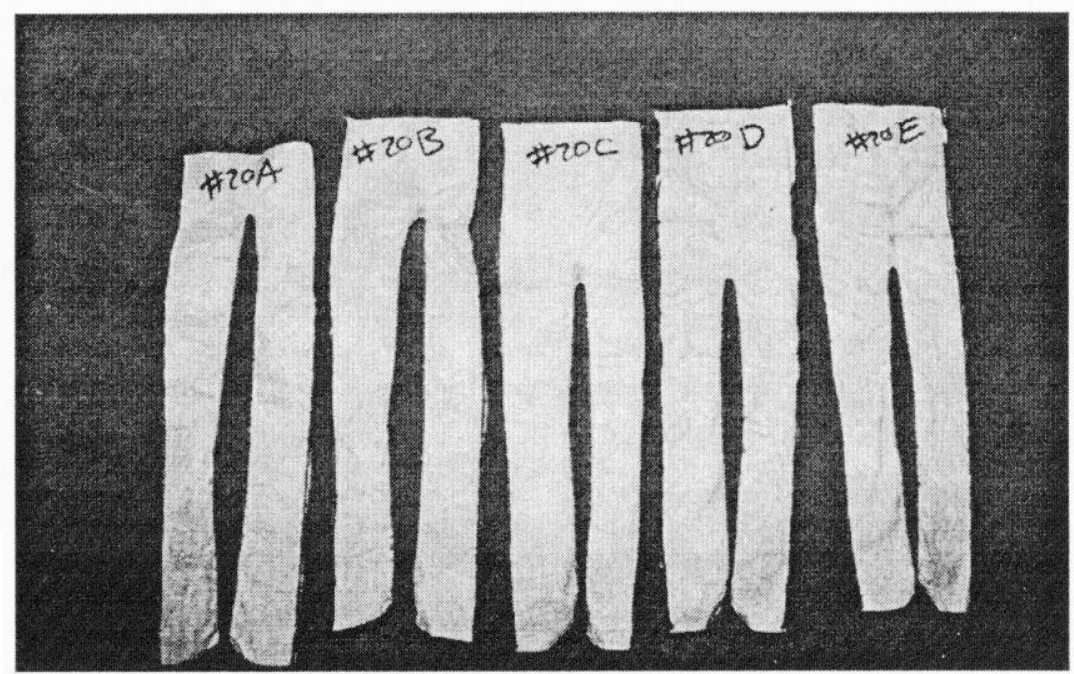

Figure 3. Moderate group.

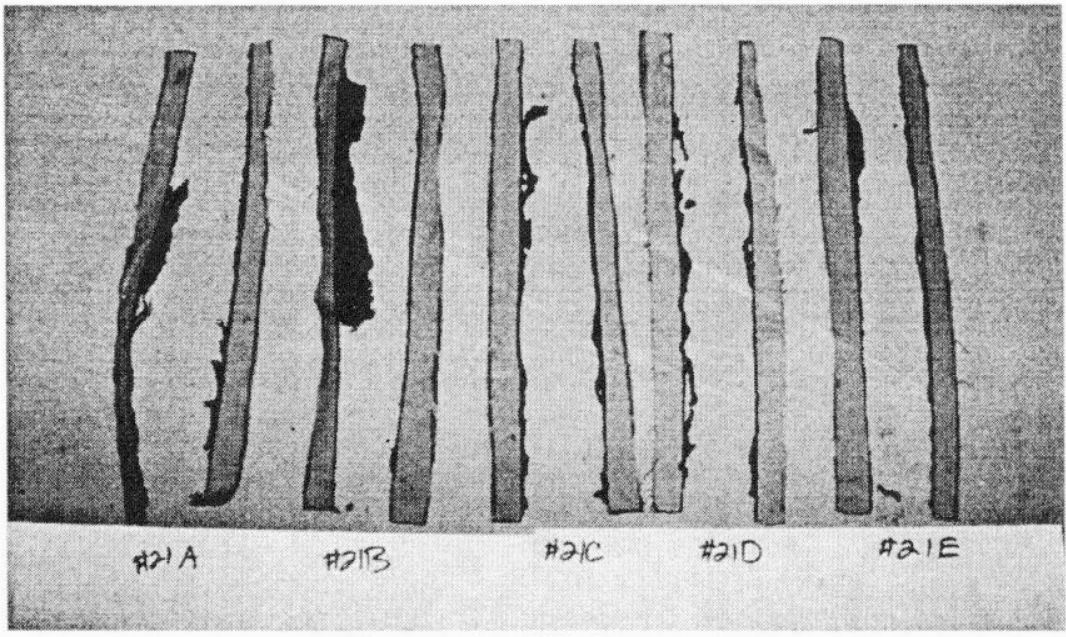

Figure 4. High group. 
layering some garments would inhibit fire growth. Thus, careful consideration must be given to garments that melt easily but do not burn. If such garments are the only layer of clothing worn, the intense heat of the melt itself will likely cause skin burns. Furthermore, if these garments are worn over more combustible clothing, the undergarments may dominate fire growth.

In situations where a garment will be exposed to ignition sources, then a fireresistant garment such as Nomex or Kevlar/PBI should be worn. If this type of garment is too costly for ongoing operations, then overgarments constructed of a lightweight material that will develop minimal flaming if ignited should be worn. Careful consideration should be given to the exposed areas of the user's body (i.e., chin, face, and hands).

Ignition of any garment from open flames, hot slags, or embers will be influenced by factors such as frayed ends, open pockets, crevices, and wrinkles. Frayed ends, particularly around the garment's cuffs, are much easier to ignite. Hot slags or embers trapped in garment folds have more time to elevate the material to ignition temperature. In addition, folds will increase the exposed surface area which can ignite and burn, reinforcing and intensifying the fire. Therefore, garments should be fitted properly with as few folds and wrinkles as possible to help guard against ignition and minimize fire growth. All pockets and cuffs should be sewn shut or removed. Garments that become frayed should be repaired or replaced immediately. Repeated laundering should be limited as much as possible, as this will wear the fabric and remove the chemical fire retardant from fire-retardant cotton coveralls.

\section{CONCLUSION}

Flammability tests were conducted at LLNL to determine the fire response and performance of various anti-contamination. Durability, wear, comfort, and other factors were not considered for this study. The results obtained were used to rank various anti-contamination garments into three risk groups (low, moderate, and high), and to provide guidance on selecting garments best suited for use in areas where ignition sources may exist. Garments in the high group should not be used in situations where contact with open flame or hot sparks is likely. Those in the moderate group should be used with discretion and additional controls. Garments in the low group are the most fire resistant and are preferable to those in the previous two groups. However, these may not be safe for use in all areas.

Code of Federal Regulation, Title 29, Part 1910.132(d) requires written hazard assessments to include the selection basis and limitations of personal protective equipment for each task. ${ }^{3}$ Thus, careful consideration must be given to both ignition sources and protective equipment needs when selecting garments for work in an area with multiple hazards (e.g., contaminants). In some cases, it may be prudent to use garments made of proven fire-resistant materials (e.g., Nomex, Kevlar/PBI) when conducting welding or pyrotechnic operations. Garments that burn with a low heatrelease rate could be used over fire-resistant garments to minimize high replacement costs. Other testing would be required to determine the flammability of such multilayered garments. 


\section{REFERENCES}

1. American Society for Testing and Materials, "Standard Test Method for Flammability of Apparel Textiles," ASTM D-1230-85 (1995).

2. General Service Administration, "Federal Standard for Textile Test Methods," Federal Test Method 191A (1978).

3. Code of Federal Regulations, Title 29, Part 1910.132, "Personal Protective Equipment-General Requirements," Occupational Safety and Health Administration, U.S. Government Printing Office, Washington DC.

\section{ACKNOWLEDGMENTS}

The authors express their gratitude to Steve Leeds, for his technical advice; Mike Trent, for bringing up this subject; Dave Myers, for providing the funding; and the ES\&H Team Leaders, for providing the test garments. 


\begin{abstract}
APPENDIX A
This appendix contains two tables with data for the samples tested. Table A-1 includes the data for samples tested using the flame exposure for the American Society for Testing and Materials (ASTM) D-1230 Standard. Table A-2 includes the data for samples tested using the flame exposure for Federal Test Method (FTM) 191 Standard.
\end{abstract}


Table A-1. Results for samples tested using the ASTM D-1230 Standard.

\begin{tabular}{|c|c|c|c|c|c|c|c|c|}
\hline Sample & Location & Group & Description $^{a}$ & $\begin{array}{c}\text { Length of flame } \\
\text { exposure (sec) }\end{array}$ & Ignition $^{b}$ & $\begin{array}{c}\text { Linear burn rate } \\
(\mathrm{cm} / \mathrm{sec})\end{array}$ & $\begin{array}{c}\text { Omni-directional } \\
\text { burn rate }(\mathrm{cm} / \mathrm{sec})\end{array}$ & $\begin{array}{c}\text { Thread time } \\
\text { (sec) }\end{array}$ \\
\hline $1 \mathrm{~A}$ & B490/491 & Low & $\begin{array}{l}\text { Green paper coveralls; model: Tempro; } \\
\text { manufacturer: Kappler; density: } 2.452 \text {. } \\
\text { Garment in new condition. }\end{array}$ & 0.978 & $\overline{\mathrm{NI}}$ & - & - & - \\
\hline 1B & B490/491 & Low & Same as above. & 1.063 & NI & - & - & - \\
\hline $1 \mathrm{C}$ & B490/491 & Low & Same as above. & 1.042 & NI & - & - & - \\
\hline $2 \mathrm{~A}$ & B490/491 & Low & $\begin{array}{l}\text { Blue paper coveralls; model: Prevail; } \\
\text { manufacturer: Kimberly-Clark; density: } \\
\text { 2.532. Garment in new condition. }\end{array}$ & 0.971 & NI & 一 & - & - \\
\hline $2 \mathrm{~B}$ & B490/491 & Low & Same as above. & 1.044 & NI & - & - & - \\
\hline $2 \mathrm{C}$ & B490/491 & Low & Same as above. & 1.042 & NI & - & - & - \\
\hline $3 A$ & $-^{c}$ & Moderate & $\begin{array}{l}\text { Yellow-coated paper coveralls that } \\
\text { resemble Durafab; density: } 2.102 \text {. } \\
\text { Garment in new condition. }\end{array}$ & 0.952 & BI & 0.324 & 0.734 & - \\
\hline 3B & $\sim^{c}$ & Moderate & Same as above. & 1.044 & LI & 0.348 & 0.569 & - \\
\hline $3 \mathrm{C}$ & $-^{c}$ & Moderate & Same as above. & 1.042 & $\mathbf{L I}$ & 0.177 & 0.356 & - \\
\hline $4 \mathrm{~A}$ & $\longrightarrow^{d}$ & Low & $\begin{array}{l}\text { Blue paper coveralls; model: Sontara; } \\
\text { manufacturer: Durafab; density: } 2.626 \text {. } \\
\text { Garment in new condition. }\end{array}$ & 0.953 & NI & - & - & - \\
\hline 4B & $-d$ & Low & Same as above. & 1.037 & NI & - & - & - \\
\hline $4 C$ & $-d$ & Low & Same as above. & 1.032 & NI & - & - & - \\
\hline
\end{tabular}

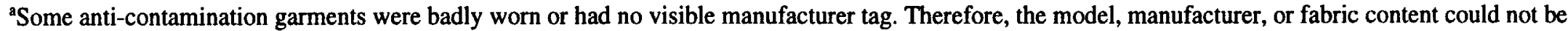
provided for all samples.

${ }^{b} \mathrm{NI}=$ no ignition; $\mathrm{BI}=$ brief ignition; $\mathrm{LI}=$ limited ignition; $\mathrm{SI}=$ sustained ignition.

${ }^{\mathrm{C}} \mathrm{Garment}$ might be from B490/491 or B175.

${ }^{\mathrm{d}} \mathrm{Garment}$ might be from B175 or B331/332. 
Table A-1. Cont'd

\begin{tabular}{|c|c|c|c|c|c|c|c|c|}
\hline Sample & Location & Group & Description $^{a}$ & $\begin{array}{l}\text { Length of flame } \\
\text { exposure (sec) }\end{array}$ & Ignition ${ }^{b}$ & $\begin{array}{l}\text { Linear burn rate } \\
\quad(\mathrm{cm} / \mathrm{sec})\end{array}$ & $\begin{array}{l}\text { Omni-directional } \\
\text { burn rate }(\mathrm{cm} / \mathrm{sec})\end{array}$ & $\begin{array}{l}\text { Thread time } \\
(\mathrm{sec})\end{array}$ \\
\hline $5 \mathrm{~A}$ & B490/491 & Moderate & $\begin{array}{l}\text { Blue- and white-coated paper coveralls; } \\
\text { model: Micro Clean 2-1-2; } \\
\text { manufacturer: Pharmaseal; density: } 1.353 \text {. } \\
\text { Garment in new condition. }\end{array}$ & 0.969 & $\overline{\mathrm{LI}}$ & 0.274 & 1.61 & - \\
\hline $5 B$ & B490/491 & Moderate & Same as above. & 1.044 & LI & 0.578 & 1.15 & - \\
\hline $5 \mathrm{C}$ & B490/491 & Moderate & Same as above. & 1.026 & $\mathrm{LI}$ & 0.563 & 0.881 & - \\
\hline $6 \mathrm{~A}$ & B391 & Moderate & $\begin{array}{l}\text { White-coated paper coveralls; } \\
\text { model: Tyvek; manufacturer: Kappler; } \\
\text { density: } 1.229 \text {. Garment in used condition. }\end{array}$ & 0.971 & $\mathrm{LI}$ & 0.105 & 0.835 & - \\
\hline $6 \mathrm{~B}$ & B391 & Moderate & Same as above. & 1.035 & LI & 0.714 & 0.779 & - \\
\hline $6 C$ & B391 & Moderate & Same as above. & 1.025 & $\mathrm{LI}$ & 0.232 & 0.958 & - \\
\hline $7 \mathrm{~A}$ & B391 & High & $\begin{array}{l}\text { Blue cloth coveralls; model: Maximun; } \\
\text { manufacturer: Dryden Engineering Co. } \\
\text { Garment in slightly used condition. }\end{array}$ & 1 & SI & - & 3.79 & 17.7 \\
\hline $7 \mathbf{B}$ & B391 & High & Same as above. & 1 & SI & - & 3.123 & 13.64 \\
\hline $7 \mathrm{C}$ & B391 & High & Same as above. & 1.033 & SI & - & 3.018 & 19.62 \\
\hline $8 \mathrm{~A}$ & B391 & High & $\begin{array}{l}\text { White cloth coveralls; model: Maximun; } \\
\text { manufacturer: Dryden Engineering Co. } \\
\text { Garment in used condition. }\end{array}$ & 1 & SI & - & 4.488 & 11.44 \\
\hline 8B & B391 & High & Same as above. & 1.039 & SI & - & 5.193 & 10 \\
\hline $8 \mathrm{C}$ & B391 & High & Same as above. & 1.03 & SI & - & 4.781 & 9.57 \\
\hline
\end{tabular}

${ }^{2}$ Some anti-contamination garments were badly worn or had no visible manufacturer tag. Therefore, the model, manufacturer, or fabric content could not be provided for all samples.

${ }^{\mathrm{b}} \mathrm{NI}=$ no ignition; $\mathrm{BI}=$ brief ignition; $\mathrm{LI}=$ limited ignition; $\mathrm{SI}$ = sustained ignition. 
Table A-1. Cont'd

\begin{tabular}{|c|c|c|c|c|c|c|c|c|}
\hline Sample & Location & Group & Description $^{\mathrm{a}}$ & $\begin{array}{l}\text { Length of flame } \\
\text { exposure (sec) }\end{array}$ & Ignition $^{b}$ & $\begin{array}{l}\text { Linear burn rate } \\
(\mathrm{cm} / \mathrm{sec})\end{array}$ & $\begin{array}{l}\text { Omni-directional } \\
\text { burn rate }(\mathrm{cm} / \mathrm{sec})\end{array}$ & $\begin{array}{l}\text { Thread time } \\
\text { (sec) }\end{array}$ \\
\hline $9 \mathrm{~A}$ & $-\mathrm{c}$ & Low & $\begin{array}{l}\text { Yellow cloth coveralls that resemble } \\
\text { Defense Apparel, Inc. Garment in used } \\
\text { condition. }\end{array}$ & 0.952 & $\mathrm{NI}$ & - & - & - \\
\hline $9 \mathrm{~B}$ & $-^{\mathfrak{c}}$ & Low & Same as above. & 1.023 & NI & - & - & - \\
\hline $9 \mathrm{C}$ & $-^{c}$ & Low & Same as above. & 1.026 & NI & - & - & - \\
\hline $10 \mathrm{~A}$ & $-\mathrm{e}$ & Moderate & $\begin{array}{l}\text { White-coated paper coveralls that resemble } \\
\text { Tyvek; density: } 1.29 . \text { Garment in used } \\
\text { condition. }\end{array}$ & 0.947 & BI & 0.208 & 0.719 & - \\
\hline $10 B$ & - $^{\mathrm{e}}$ & Moderate & Same as above. & 1.029 & BI & 1.429 & 0.737 & - \\
\hline $10 \mathrm{C}$ & $-^{e}$ & Moderate & Same as above. & 1.006 & LI & 0.769 & 0.783 & - \\
\hline $11 \mathrm{~A}$ & Plant Eng & Low & $\begin{array}{l}\text { 100\% Polypropylene coveralls, style GB- } \\
1030 \text {; density: } 1.503 \text {. Garment in } \\
\text { slightly used condition. }\end{array}$ & 0.947 & NI & - & - & - \\
\hline $11 B$ & Plant Eng & Low & Same as above. & 1.041 & NI & 一 & - & - \\
\hline $11 \mathrm{C}$ & Plant Eng & Low & Same as above. & 1.005 & NI & 一 & - & - \\
\hline $12 \mathrm{~A}$ & $\begin{array}{c}\text { B321 A } \\
\text { (main bay) }\end{array}$ & Low & $\begin{array}{l}\text { Blue lab coat, } 65 \% \text { polyester and } 35 \% \\
\text { cotton. Garment in worn condition. }\end{array}$ & 0.934 & NI & - & - & - \\
\hline $12 \mathrm{~B}$ & $\begin{array}{c}\text { B321 A } \\
\text { (main bay) }\end{array}$ & Low & Same as above. & 1.032 & NI & 一 & 一 & - \\
\hline $12 \mathrm{C}$ & $\begin{array}{c}\text { B321 A } \\
\text { (main bay) }\end{array}$ & Low & Same as above. & 1.032 & NI & - & - & - \\
\hline
\end{tabular}

aSome anti-contamination garments were badly worn or had no visible manufacturer tag. Therefore, the model, manufacturer, or fabric content could not be provided for all samples.

${ }^{\mathrm{b}} \mathrm{NI}=$ no ignition; $\mathrm{BI}=$ brief ignition; $\mathrm{LI}=$ limited ignition; $\mathrm{SI}=$ sustained ignition.

'Garment might be from B490/491 or B175.

${ }^{\circ} \mathrm{Garment}$ is probably from B361. 
Table A-1. Cont'd

\begin{tabular}{|c|c|c|c|c|c|c|c|c|}
\hline Sample & Location & Group & Description $^{\mathrm{a}}$ & $\begin{array}{c}\text { Length of flame } \\
\text { exposure (sec) }\end{array}$ & Ignition $^{\mathrm{b}}$ & $\begin{array}{l}\text { Linear burn rate } \\
(\mathrm{cm} / \mathrm{sec})\end{array}$ & $\begin{array}{l}\text { Omni-directional } \\
\text { burn rate }(\mathrm{cm} / \mathrm{sec})\end{array}$ & $\begin{array}{l}\text { Thread time } \\
(\mathrm{sec})\end{array}$ \\
\hline $13 \mathrm{~A}$ & $\begin{array}{c}\text { B321 C } \\
\text { (nc shop) }\end{array}$ & Low & $\begin{array}{l}\text { Orange lab coat, } 65 \% \text { polyester and } 35 \% \\
\text { cotton; manufacturer: Euclid. Garment in } \\
\text { worn condition. }\end{array}$ & 0.935 & $\overline{\mathrm{NI}}$ & - & - & - \\
\hline 13B & $\begin{array}{l}\text { B321 C } \\
\text { (nc shop) }\end{array}$ & Low & Same as above. & 1.022 & NI & - & - & - \\
\hline $13 \mathrm{C}$ & $\begin{array}{l}\text { B321 C } \\
\text { (nc shop) }\end{array}$ & Low & Same as above. & 1.047 & NI & - & - & - \\
\hline $14 \mathrm{~A}$ & $\begin{array}{c}\text { B321 A } \\
\text { (main bay) }\end{array}$ & Low & $\begin{array}{l}\text { Blue lab coat, } 50 \% \text { polyester and } 50 \% \\
\text { cotton; manufacturer: Uniforms } \\
\text { Manufacturer, Inc. Garment in used } \\
\text { condition. }\end{array}$ & 0.962 & NI & - & - & - \\
\hline 14B & $\begin{array}{c}\text { B321 } \mathrm{A} \\
\text { (main bay) }\end{array}$ & Low & Same as above. & 1.026 & NI & - & - & - \\
\hline $14 \mathrm{C}$ & $\begin{array}{c}\text { B321 A } \\
\text { (main bay) }\end{array}$ & Low & Same as above. & 1.032 & NI & - & 一 & - \\
\hline $15 \mathrm{~A}$ & B321 & Low & $\begin{array}{l}\text { White and orange lab coat. Garment in } \\
\text { badly worn condition. }\end{array}$ & 0.932 & NI & - & - & - \\
\hline $15 B$ & B321 & Low & Same as above. & 1.022 & NI & - & - & - \\
\hline $15 \mathrm{C}$ & B321 & Low & Same as above. & 1.014 & NI & - & - & - \\
\hline $16 \mathrm{~A}$ & $\begin{array}{c}\text { B321 } \mathrm{A} \\
\text { (main bay) }\end{array}$ & Low & Blue lab coat. Garment in worn condition. & 0.936 & NI & - & - & - \\
\hline $16 \mathrm{~B}$ & $\begin{array}{l}\text { B321 A } \\
\text { (main bay) }\end{array}$ & Low & Same as above. & 1.031 & NI & - & - & - \\
\hline $16 \mathrm{C}$ & $\begin{array}{c}\text { B321 A } \\
\text { (main bay) }\end{array}$ & Low & Same as above. & 1.031 & NI & - & - & - \\
\hline
\end{tabular}

aSome anti-contamination garments were badly worn or had no visible manufacturer tag. Therefore, the model, manufacturer, or fabric content could not be provided for all samples.

${ }^{\mathrm{b}} \mathrm{NI}=$ no ignition; $\mathrm{BI}=$ brief ignition; $\mathrm{LI}=$ limited ignition; $\mathrm{SI}=$ sustained ignition.

inc shop = numerically controlled (special material) machine shop. 
Table A-1. Cont'd

\begin{tabular}{|c|c|c|c|c|c|c|c|c|}
\hline Sample & Location & Group & Description $^{\mathrm{a}}$ & $\begin{array}{l}\text { Length of flame } \\
\text { exposure (sec) }\end{array}$ & Ignition $^{b}$ & $\begin{array}{l}\text { Linear burn rate } \\
(\mathrm{cm} / \mathrm{sec})\end{array}$ & $\begin{array}{l}\text { Omni-directional } \\
\text { burn rate }(\mathrm{cm} / \mathrm{sec})\end{array}$ & $\begin{array}{l}\text { Thread time } \\
(\mathrm{sec})\end{array}$ \\
\hline $17 \mathrm{~A}$ & $\begin{array}{c}\text { B321 A } \\
\text { (main bay) }\end{array}$ & Low & $\begin{array}{l}\text { Blue lab coat, } 65 \% \text { dacron and } 35 \% \text { cotton; } \\
\text { manufacturer: } \mathrm{KWB} \text { Manufacturing Co. } \\
\text { Garment in worn condition. }\end{array}$ & 1.076 & NI & - & - & - \\
\hline $17 \mathrm{~B}$ & $\begin{array}{c}\text { B321 A } \\
\text { (main bay) }\end{array}$ & Low & Same as above. & 1.032 & NI & - & - & - \\
\hline $17 \mathrm{C}$ & $\begin{array}{c}\text { B321 A } \\
\text { (main bay) }\end{array}$ & Low & Same as above. & 1.006 & NI & - & - & - \\
\hline $18 \mathrm{~A}$ & B321 C & Low & $\begin{array}{l}\text { White lab coat, } 65 \% \text { polyester and } 35 \% \\
\text { cotton; manufacturer: Best Manufacturing } \\
\text { Co. Garment in worn condition. }\end{array}$ & 0.95 & NI & - & - & - \\
\hline 18B & B321 C & Low & Same as above. & 1.02 & NI & - & - & - \\
\hline $18 \mathrm{C}$ & B321 C & Low & Same as above. & 1.029 & NI & - & - & - \\
\hline $19 \mathrm{~A}$ & B332 & Low & $\begin{array}{l}\text { Yellow cloth coveralls that resemble } \\
\text { Defense Apparel, Inc. Garment in new } \\
\text { condition. }\end{array}$ & 0.954 & NI & 一 & - & - \\
\hline 19B & B332 & Low & Same as above. & 1.024 & NI & - & - & - \\
\hline $19 \mathrm{C}$ & B332 & Low & Same as above. & 1.042 & NI & - & - & - \\
\hline $20 \mathrm{~A}$ & B331 & Moderate & $\begin{array}{l}\text { White, full body suit; model: Tyvek; } \\
\text { manufacturer: Kappler; density: } 1.324 \text {. } \\
\text { Garment in new condition. }\end{array}$ & 1.097 & LI & 0.214 & 1.232 & - \\
\hline $20 \mathrm{~B}$ & B331 & Moderate & Same as above. & 1.019 & BI & 0.6 & 0.546 & - \\
\hline $20 \mathrm{C}$ & B331 & Moderate & Same as above. & 1.031 & LI & 0.363 & 1.028 & - \\
\hline
\end{tabular}

${ }^{\text {aS }}$ ome anti-contamination garments were badly worn or had no visible manufacturer tag. Therefore, the model, manufacturer, or fabric content could not be provided for all samples.

${ }^{\mathrm{b}} \mathrm{NI}=$ no ignition; $\mathrm{BI}=$ brief ignition; $\mathrm{LI}=$ limited ignition; $\mathrm{SI}$ = sustained ignition . 
Table A-1. Cont'd

\begin{tabular}{|c|c|c|c|c|c|c|c|c|}
\hline Sample & Location & Group & Description ${ }^{2}$ & $\begin{array}{c}\text { Length of flame } \\
\text { exposure (sec) }\end{array}$ & Ignition $^{\mathrm{b}}$ & $\begin{array}{l}\text { Linear burn rate } \\
(\mathrm{cm} / \mathrm{sec})\end{array}$ & $\begin{array}{l}\text { Omni-directional } \\
\text { burn rate }(\mathrm{cm} / \mathrm{sec})\end{array}$ & $\begin{array}{l}\text { Thread time } \\
\text { (sec) }\end{array}$ \\
\hline $21 \mathrm{~A}$ & B321 C & Low & $\begin{array}{l}\text { Orange lab coat, } 65 \% \text { polyester and } 35 \% \\
\text { cotton, possibly style } 52-\mathrm{RG} \text {; } \\
\text { manufacturer: Wranglers. Garment in used } \\
\text { condition. }\end{array}$ & 0.952 & $\mathbf{N I}$ & - & - & - \\
\hline $21 \mathrm{~B}$ & B321 C & Low & Same as above. & 1.033 & NI & - & - & - \\
\hline $21 \mathrm{C}$ & B321 C & Low & Same as above. & 1.049 & NI & - & - & - \\
\hline 22B & B332 & Low & Same as above. & 1.033 & NI & - & - & - \\
\hline $22 \mathrm{C}$ & B332 & Low & Same as above. & 1.005 & NI & - & - & - \\
\hline
\end{tabular}

aSome anti-contamination garments were badly worn or had no visible manufacturer tag. Therefore, the model, manufacturer, or fabric content could not be provided for all samples.

${ }^{b} \mathrm{NI}=$ no ignition; $\mathrm{BI}=$ brief ignition; $\mathrm{LI}=$ limited ignition; $\mathrm{SI}$ = sustained ignition. 
Table A-2. Results for samples tested using the FTM 191 Standard.

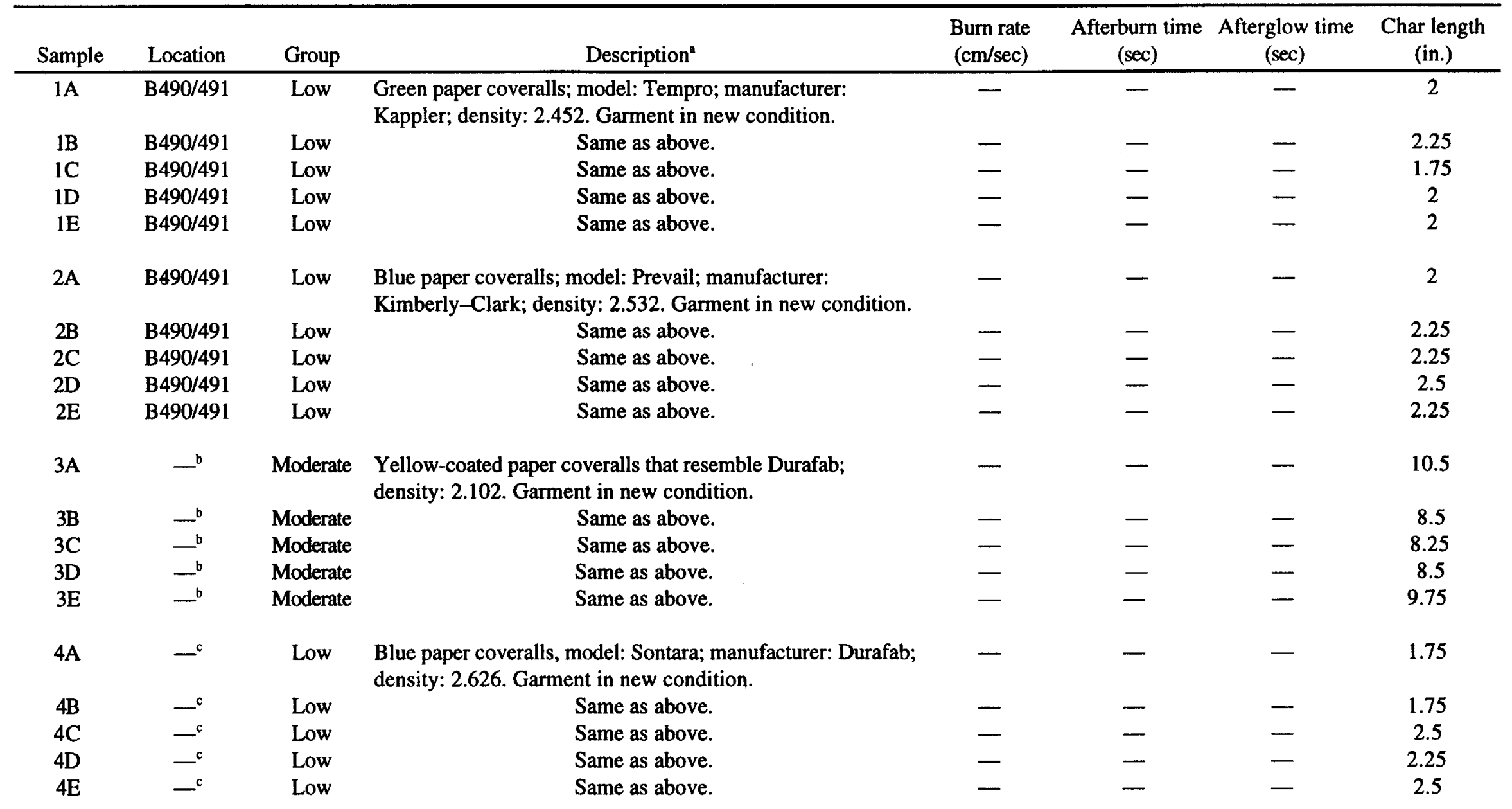

${ }^{2}$ Some anti-contamination garments were badly worn or had no visible manufacturer's tag. Therefore, the model, manufacturer, or fabric content could not be provided for all samples.

${ }^{\mathrm{b}}$ Garment might be from B490/491 or B175.

${ }^{\mathrm{c}} \mathrm{Garment}$ might be from B175 or B331/332. 
Table A-2. Cont'd

\begin{tabular}{|c|c|c|c|c|c|c|c|}
\hline Sample & Location & Group & Description $^{a}$ & $\begin{array}{l}\text { Burn rate } \\
(\mathrm{cm} / \mathrm{sec})\end{array}$ & $\begin{array}{l}\text { Afterburn time } \\
\quad(\mathrm{sec})\end{array}$ & $\begin{array}{l}\text { Afterglow time } \\
\text { (sec) }\end{array}$ & $\begin{array}{l}\text { Char length } \\
\text { (in.) }\end{array}$ \\
\hline $5 \mathrm{~A}$ & B490/491 & Moderate & $\begin{array}{l}\text { Blue- and white-coated paper coveralls; model: Micro Clean } \\
\text { 2-1-2; manufacturer: Pharmaseal; density: } 1.353 \text {. Garment } \\
\text { in new condition. }\end{array}$ & - & - & - & 10.5 \\
\hline $5 B$ & B490/491 & High & Same as above. & - & - & - & 11 \\
\hline $5 C$ & B490/491 & High & Same as above. & - & - & - & 10.75 \\
\hline $5 \mathrm{D}$ & B490/491 & Moderate & Same as above. & - & - & - & 9.5 \\
\hline $5 \mathrm{E}$ & B490/491 & High & Same as above. & - & - & - & 11 \\
\hline $6 \mathrm{~A}$ & B391 & High & $\begin{array}{l}\text { White-coated paper coveralls; model: Tyvek; manufacturer: } \\
\text { Kappler; density: } 1.229 \text {. Garment in used condition. }\end{array}$ & - & - & - & 12 \\
\hline $6 \mathrm{~B}$ & B391 & High & Same as above. & - & - & - & 11.75 \\
\hline $6 \mathrm{C}$ & B391 & High & Same as above. & - & - & - & 11 \\
\hline $6 \mathrm{D}$ & B391 & Moderate & Same as above. & - & - & - & 10.5 \\
\hline $6 \mathrm{E}$ & B391 & High & Same as above. & - & - & - & 11.5 \\
\hline 7D & B391 & Low & Same as above. & - & - & - & - \\
\hline $7 \mathrm{E}$ & B391 & Moderate & Same as above. & 0.598 & 26 & - & - \\
\hline $8 \mathrm{~A}$ & B391 & Moderate & $\begin{array}{l}\text { White cloth coveralls; model: Maximun; manufacturer: } \\
\text { Dryden Engineering Co. Garment in used condition. }\end{array}$ & 0.7257 & 12 & - & - \\
\hline $8 \mathrm{~B}$ & B391 & Moderate & Same as above. & 1.27 & 43 & - & - \\
\hline $8 \mathrm{C}$ & B391 & Moderate & Same as above. & 1.693 & 17 & - & - \\
\hline 8D & B391 & Moderate & Same as above. & 1.693 & 30 & - & - \\
\hline $8 \mathrm{E}$ & B391 & Moderate & Same as above. & 1.494 & 21.2 & - & - \\
\hline
\end{tabular}

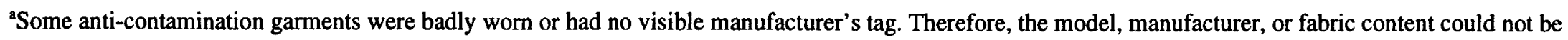
provided for all samples.

${ }^{\mathrm{N}}$ No forward propagation of flame after source removal. 
Table A-2. Cont'd

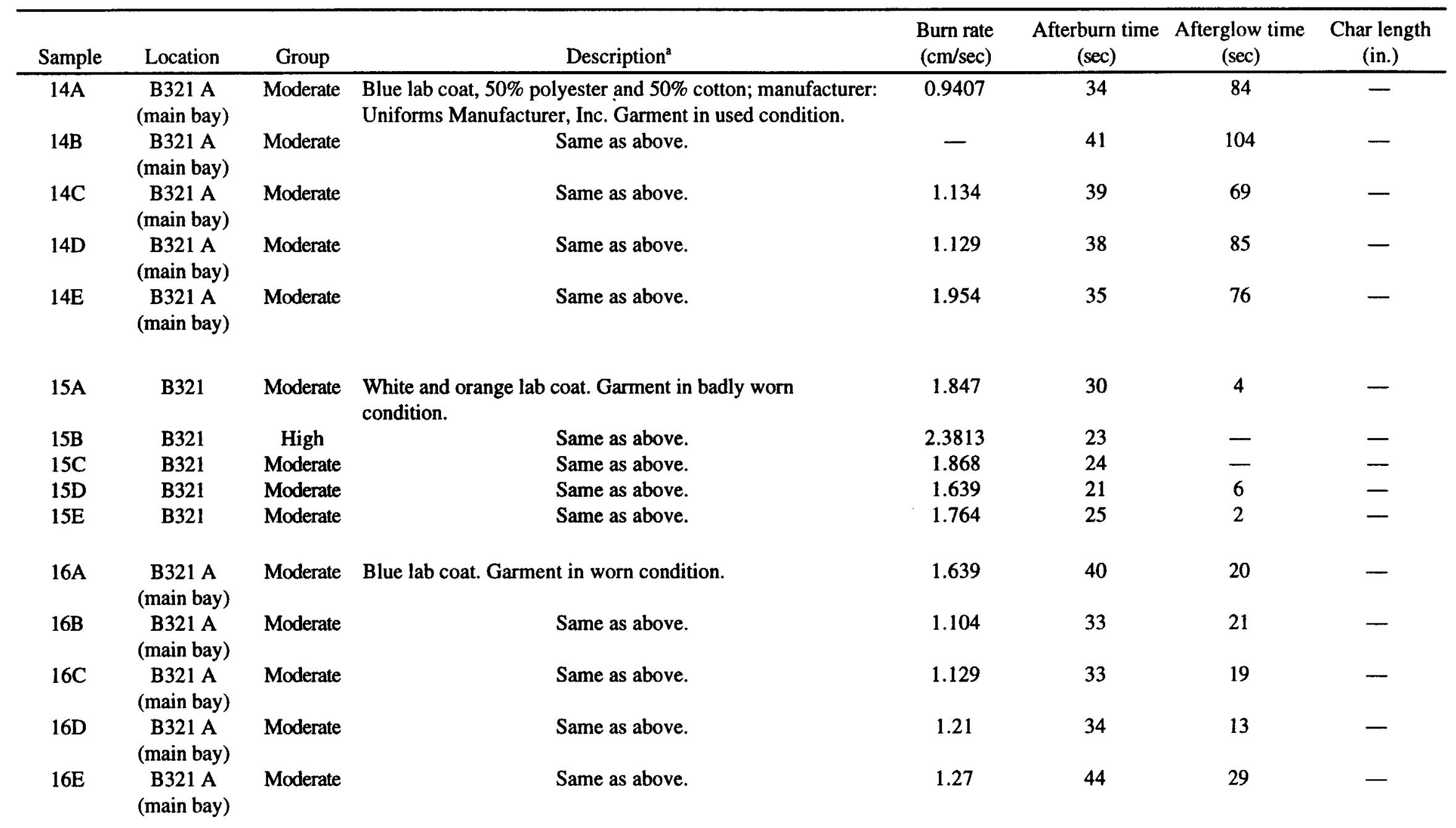

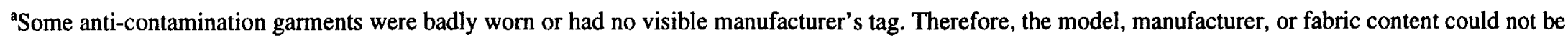
provided for all samples. 
Table A-2. Cont'd

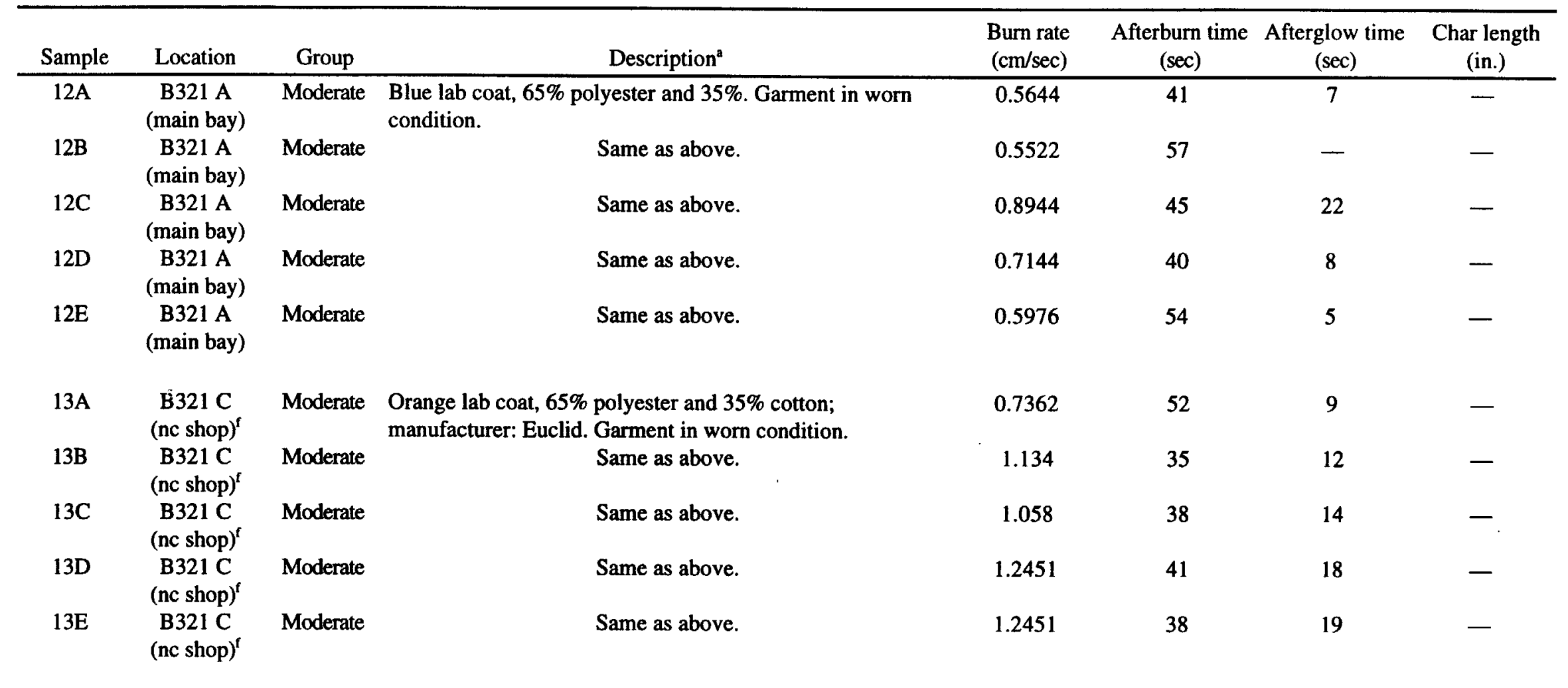

a'Some anti-contamination garments were badly worn or had no visible manufacturer's tag. Therefore, the model, manufacturer, or fabric content could not be provided for all samples.

${ }^{i} \mathrm{nc}$ shop $=$ numerically controlled (special material) machine shop. 
Table A-2. Cont'd

\begin{tabular}{|c|c|c|c|c|c|c|c|}
\hline Sample & Location & Group & Description $^{\mathrm{a}}$ & $\begin{array}{r}\text { Burn rate } \\
(\mathrm{cm} / \mathrm{sec})\end{array}$ & $\begin{array}{l}\text { Afterburn time } \\
(\mathrm{sec})\end{array}$ & $\begin{array}{l}\text { Afterglow time } \\
(\mathrm{sec})\end{array}$ & $\begin{array}{c}\text { Char length } \\
\text { (in.) }\end{array}$ \\
\hline $14 \mathrm{~A}$ & $\begin{array}{c}\text { B321 A } \\
\text { (main bay) }\end{array}$ & Moderate & $\begin{array}{l}\text { Blue lab coat, } 50 \% \text { polyester and } 50 \% \text { cotton; manufacturer: } \\
\text { Uniforms Manufacturer, Inc. Garment in used condition. }\end{array}$ & 0.9407 & 34 & 84 & - \\
\hline $14 \mathrm{C}$ & $\begin{array}{c}\text { B321 A } \\
\text { (main bay) }\end{array}$ & Moderate & Same as above. & 1.134 & 39 & 69 & - \\
\hline $15 \mathrm{~A}$ & B321 & Moderate & $\begin{array}{l}\text { White and orange lab coat. Garment in badly worn } \\
\text { condition. }\end{array}$ & 1.847 & 30 & 4 & - \\
\hline $15 B$ & B321 & High & Same as above. & 2.3813 & 23 & - & - \\
\hline $15 \mathrm{C}$ & B321 & Moderate & Same as above. & 1.868 & 24 & - & - \\
\hline $16 B$ & $\begin{array}{c}\text { B321 A } \\
\text { (main bay) }\end{array}$ & Moderate & Same as above. & 1.104 & 33 & 21 & - \\
\hline $16 \mathrm{C}$ & $\begin{array}{l}\text { B321 A } \\
\text { (main bay) }\end{array}$ & Moderate & Same as above. & 1.129 & 33 & 19 & - \\
\hline $16 \mathrm{D}$ & $\begin{array}{l}\text { B321 A } \\
\text { (main bay) }\end{array}$ & Moderate & Same as above. & 1.21 & 34 & 13 & - \\
\hline $16 \mathrm{E}$ & $\begin{array}{c}\text { B321 A } \\
\text { (main bay) }\end{array}$ & Moderate & Same as above. & 1.27 & 44 & 29 & - \\
\hline
\end{tabular}

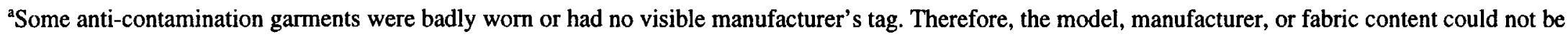
provided for all samples. 
Table A-2. Cont'd

\begin{tabular}{|c|c|c|c|c|c|c|c|}
\hline Sample & Location & Group & Description $^{\mathrm{a}}$ & $\begin{array}{l}\text { Burn rate } \\
(\mathrm{cm} / \mathrm{sec})\end{array}$ & $\begin{array}{l}\text { Afterburn time } \\
\quad(\mathrm{sec})\end{array}$ & $\begin{array}{l}\text { Afterglow time } \\
\qquad(\mathrm{sec})\end{array}$ & $\begin{array}{l}\text { Char length } \\
\quad \text { (in.) }\end{array}$ \\
\hline $17 \mathrm{C}$ & $\begin{array}{l}\text { B321 A } \\
\text { (main bay) }\end{array}$ & Moderate & Same as above. & 1.089 & 39 & 25 & 一 \\
\hline 17D & $\begin{array}{l}\text { B321 A } \\
\text { (main bay) }\end{array}$ & Moderate & Same as above. & 1.176 & 94 & 39 & - \\
\hline $18 \mathrm{~A}$ & B321 C & High & $\begin{array}{l}\text { White lab coat, } 65 \% \text { polyester and } 35 \% \text { cotton; } \\
\text { manufacturer: Best Manufacturing Co. Garment in worn } \\
\text { condition. }\end{array}$ & 2.117 & 27 & 22 & - \\
\hline $18 B$ & B321 C & Moderate & Same as above. & 1.524 & 24 & 30 & - \\
\hline $18 \mathrm{C}$ & B321 C & High & Same as above. & 2.54 & 23 & 11 & - \\
\hline 18D & B321 C & Moderate & Same as above. & 1.588 & 25 & 5 & - \\
\hline $18 \mathrm{E}$ & B321 C & Moderate & Same as above. & 1.671 & 25 & 7 & - \\
\hline $19 \mathrm{~A}$ & B332 & Moderate & $\begin{array}{l}\text { Yellow cloth coveralls that resemble Defense Apparel, Inc. } \\
\text { Garment in used condition. }\end{array}$ & 1.451 & 36 & 37 & - \\
\hline 19B & B332 & Moderate & Same as above. & 1.8143 & 35 & 25 & - \\
\hline $19 \mathrm{C}$ & B332 & Moderate & Same as above. & 1.693 & 36 & 36 & - \\
\hline 19D & B332 & Moderate & Same as above. & 1.958 & 35 & 47 & - \\
\hline $19 E$ & B332 & Moderate & Same as above. & 2.048 & 34 & 25 & - \\
\hline
\end{tabular}

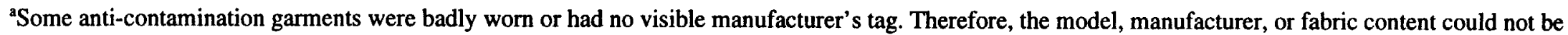
provided for all samples. 
Table A-2. Cont'd

\begin{tabular}{|c|c|c|c|c|c|c|c|}
\hline Sample & Location & Group & Description $^{2}$ & $\begin{array}{l}\text { Burn rate } \\
(\mathrm{cm} / \mathrm{sec})\end{array}$ & $\begin{array}{l}\text { Afterburn time } \\
\text { (sec) }\end{array}$ & $\begin{array}{l}\text { Afterglow time } \\
\quad(\mathrm{sec})\end{array}$ & $\begin{array}{l}\text { Char length } \\
\text { (in.) }\end{array}$ \\
\hline $20 \mathrm{~A}$ & B331 & Moderate & $\begin{array}{l}\text { White, full body suit; model: Tyvek; manufacturer: Kappler; } \\
\text { density: } 1.324 \text {. Garment in new condition. }\end{array}$ & - & - & - & 10 \\
\hline 20B & B331 & Moderate & Same as above. & - & - & - & 9.25 \\
\hline $20 \mathrm{C}$ & B331 & Moderate & Same as above. & - & - & - & 8 \\
\hline 20D & B331 & Moderate & Same as above. & - & - & - & 7.75 \\
\hline $20 \mathrm{E}$ & B331 & Moderate & Same as above. & - & - & - & 7.75 \\
\hline $21 \mathrm{~A}$ & B321 C & High & $\begin{array}{l}\text { Orange lab coat, } 65 \% \text { polyester and } 35 \% \text { cotton, possibly } \\
\text { style } 52-\text { RG; manufacturer: Wranglers. Garment in used } \\
\text { condition. }\end{array}$ & 2.032 & 29 & 8 & - \\
\hline 21B & B321 C & Moderate & Same as above. & 1.355 & 21 & 6 & - \\
\hline $21 \mathrm{C}$ & B321 C & High & Same as above. & 2.177 & 24 & 3 & - \\
\hline 21D & B321 C & High & Same as above. & 2.628 & 18 & 6 & - \\
\hline $21 \mathrm{E}$ & B321 C & High & Same as above. & 3.266 & 28 & 4 & 一 \\
\hline $22 \mathrm{~A}$ & B332 & Moderate & $\begin{array}{l}\text { Orange coveralls, } 65 \% \text { polyester and } 35 \% \text { cotton. Garment in } \\
\text { used condition. }\end{array}$ & 0.847 & 48 & 6 & - \\
\hline 22B & B332 & Moderate & Same as above. & 0.577 & 39 & 6 & - \\
\hline $22 \mathrm{C}$ & B332 & Moderate & Same as above. & 0.693 & 44 & 12 & - \\
\hline 22D & B332 & Moderate & Same as above. & 0.896 & 40 & 7 & - \\
\hline $22 \mathrm{E}$ & B332 & Moderate & Same as above. & 0.747 & 44 & 5 & - \\
\hline
\end{tabular}

aSome anti-contamination garments were badly worn or had no visible manufacturer's tag. Therefore, the model, manufacturer, or fabric content could not be provided for all samples. 


$$
-\quad
$$




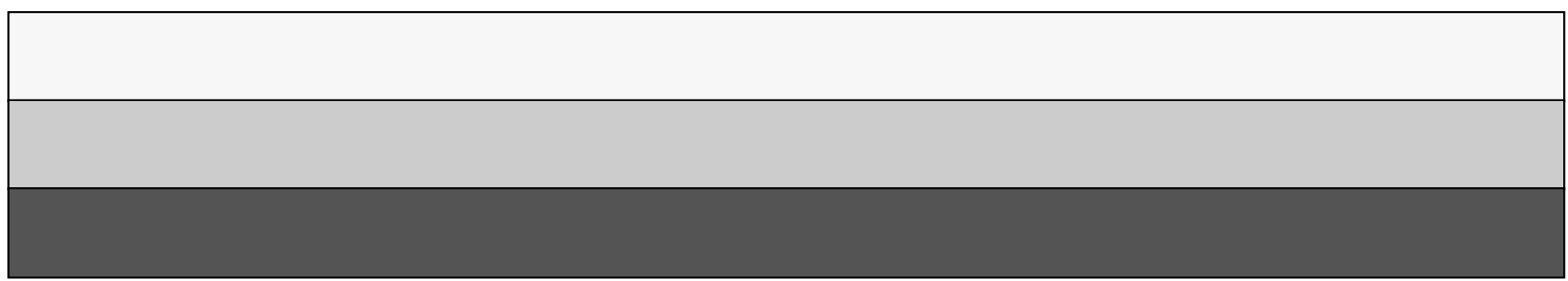

